\title{
Factors Influencing the Susceptibility of Candida albicans to the Polyenoic Antibiotics Nystatin and Amphotericin B
}

\author{
By B. JOHNSON, REBECCA J. WHITE* AND G. M. WILLIAMSON \\ Department of Microbiology, The Medical School, The University, \\ Newcastle upon Tyne NE1 7RU
}

(Received 13 May 1977; revised 27 September 1977)

Factors influencing the interaction between Candida albicans and the polyenoic antibiotics nystatin and amphotericin $\mathbf{B}$ have been investigated using a $\mathbf{K}^{+}$-specific electrode to measure polyene-mediated efflux of cellular $\mathrm{K}^{+}$. In batch cultures, sensitivity was a function of culture age. Using continuous (chemostat) cultures, the influence of growth-limiting substrate, specific growth rate, growth temperature and growth $\mathrm{pH}$ were examined. Carbonlimited cultures showed the highest sensitivity of those substrates tested, and susceptibility increased with growth rate. Within the range 22 to $42{ }^{\circ} \mathrm{C}$, growth at lower temperatures resulted in increased sensitivity, whilst a similar trend was observed when the growth $\mathrm{pH}$ of cultures was reduced. Further, under the conditions tested, there were considerable variations in free intracellular $\mathrm{K}^{+}$concentrations.

\section{INTRODUCTION}

The majority of polyenoic antibiotics, which exhibit antifungal properties, are straightchain conjugated molecules having a macrocyclic lactone ring with rigid lipophilic and flexible hydrophilic portions (see Hamilton-Miller, 1973). Several are used clinically to combat infections with the yeast Candida albicans, an opportunistic pathogen (see Cartwright, 1975). The antifungal activity of the polyenes is due to their interaction with the sterols of the cytoplasmic membrane thereby causing loss of selective permeability and the subsequent death of the organism (Lampen, 1966). This is believed to be due to the formation of molecular-sized pores in the membrane (Holz, 1974; McLaughlin \& Eisenberg, 1975). Different polyenes cause various degrees of damage to the membrane, those of smaller size having greater effects than those of larger size (Lampen, 1966; Borowski \& Cybulska, 1967); this is reflected in the size of the intracellular molecular and ionic species which are released after polyene treatment. However, most polyenes thus far examined induce the loss of potassium ions $\left(\mathrm{K}^{+}\right)$from sensitive organisms (Lampen, 1966; Zygmunt, 1966). Such $\mathrm{K}^{+}$loss has been exploited as a method of monitoring the interaction of polyenes with susceptible cells (Hammond, Lambert \& Kliger, 1974; Gale, 1974).

Several investigations, using cell populations grown in batch culture, have indicated that the conditions under which an organism is grown may influence the cell/antibiotic interaction. Hammond \& Kliger (1974), Hammond et al. (1974) and Gale (1974) have shown the relative susceptibility of $C$. albicans to nystatin, amphotericin B and amphotericin B methyl ester, as measured by $\mathrm{K}^{+}$release, to be dependent upon the age of the culture, cell populations becoming progressively more resistant with age. Venables \& Russell (1975),

\footnotetext{
* Present address: Department of Microbiology, The London Hospital, Whitechapel, London.
} 
working with Saccharomyces cerevisiae, demonstrated that the rate of nystatin uptake was inversely related to the growth temperatures used.

However, caution should be exercised in the interpretation of such data since growth in batch culture results in a rapidly changing environment and a physiologically heterogeneous cell population. Further, under such conditions it is impossible to assess the effects of any single parameter of growth. One solution to these objections is to use the rigorously defined conditions of growth provided by continuous (chemostat) cultures. Such an approach has proved fruitful in an investigation of the interaction of Pseudomonas aeruginosa with the antibiotic polymyxin B (Finch \& Brown, 1975).

The present paper reports the separate effects of growth parameters upon the sensitivity of chemostat-grown $C$. albicans to the polyenoic antibiotics nystatin and amphotericin B, as measured by $\mathrm{K}^{+}$release. Further, we have attempted to assess the effect of the total free intracellular $\mathrm{K}^{+}$concentration upon such leakage since if, as seems probable, the intracellular $\mathrm{K}^{+}$concentration varies with growth conditions, then it may be an important factor in determining the rate of $\mathrm{K}^{+}$release from polyene-treated cells. If such $\mathrm{K}^{+}$release is to be used objectively to monitor the effects of polyenes upon susceptible cell populations, then it is imperative to know the possible influence upon $\mathrm{K}^{+}$release of variations in the free intracellular $\mathrm{K}^{+}$concentration of such cells, a factor which has not been recognized by previous workers.

\section{METHODS}

Organism. Candida albicans 6406, originally a clinical isolate of the Mycological Reference Laboratory, London School of Hygiene and Tropical Medicine, was kindly donated by Professor E. F. Gale, SubDepartment of Chemical Microbiology, Department of Biochemistry, University of Cambridge. It was maintained by monthly subculture on $1 \%(w / v)$ yeast extract (Oxoid), $2 \%(w / v)$ peptone (Oxoid), $2 \%$ (w/v) D-glucose agar.

Chemicals. All chemicals used were of the highest grade of purity commercially available.

Batch cultures. These were grown at $37{ }^{\circ} \mathrm{C}$ in an orbital shaker incubator (Gallenkamp) in $400 \mathrm{ml}$ portions (in 1 litre flasks) of either Sabouraud medium (containing $10 \mathrm{~g}$ mycological peptone (Oxoid) and $40 \mathrm{~g}$ $\mathrm{D}$-glucose in 1 litre glass-distilled water, $\mathrm{pH} 5 \cdot 0$ ) or defined continuous culture medium (CCM), pH 5.0, with all components in excess (for composition see below).

Continuous cultures. The organism was grown in a 'Porton-type' chemostat of working volume 1 litre. Temperature was monitored and controlled by a resistance thermometer linked to a temperature indicator/ controller (Bikini model; Fielden Electronics, Paston Road, Manchester). The pH was monitored and controlled by an autoclavable, dismountable $\mathrm{pH}$ electrode (Activion, Kinglassie, Fife) in the vessel linked to a pH indicator/controller (model 9150; Electronics Industries, Chertsey, Surrey). Aeration was achieved by sparging sterile air (1 litre $\mathrm{min}^{-1}$ ) into the culture vessel (fitted with baffles) and stirring the culture via a top-drive impeller at $750 \mathrm{rev} . \mathrm{min}^{-1}$. Growth medium was added at the required rate whilst the culture volume was maintained by means of a weir overflow.

The CCM employed were as follows ( $\mathrm{mmol}^{-1}$ in glass-distilled water). Carbon (glucose) limited: Dglucose, 11.1; $\left(\mathrm{NH}_{4}\right)_{2} \mathrm{SO}_{4}, 22 \cdot 7 ; \mathrm{KH}_{2} \mathrm{PO}_{4}, 7 \cdot 3 ; \mathrm{MgSO}_{4}, 4 \cdot 1 ; \mathrm{CaCl}_{2}, 1 \cdot 1$. Nitrogen (ammonium) limited: D-glucose, 83.3; $\left(\mathrm{NH}_{4}\right)_{2} \mathrm{SO}_{4}, 1 \cdot 8 ; \mathrm{KH}_{2} \mathrm{PO}_{4}, 7 \cdot 3 ; \mathrm{MgSO}_{4}, 4 \cdot 1 ; \mathrm{CaCl}_{2}, 1 \cdot 1$. Phosphorus (phosphate) limited: D-glucose, 83.3; $\left(\mathrm{NH}_{4}\right)_{2} \mathrm{SO}_{4}, 22 \cdot 7 ; \mathrm{KH}_{2} \mathrm{PO}_{4}, 0 \cdot 2 ; \mathrm{MgSO}_{4}, 4 \cdot 1 ; \mathrm{CaCl}_{2}, 1 \cdot 1 ; \mathrm{KCl}, 6 \cdot 7$. Sulphur (sulphate) limited: D-glucose, 83.3; $\mathrm{NH}_{4} \mathrm{Cl}, 30 \cdot 0 ; \mathrm{KH}_{2} \mathrm{PO}_{4}, 7 \cdot 3 ; \mathrm{MgSO}_{4}, 0 \cdot 1 ; \mathrm{CaCl}_{2}, 1 \cdot 1 ; \mathrm{MgCl}_{2}, 4 \cdot 0$. Magnesium limited: D-glucose, 83.3; $\left(\mathrm{NH}_{4}\right)_{2} \mathrm{SO}_{4}, 22 \cdot 7 ; \mathrm{KH}_{2} \mathrm{PO}_{4}, 7 \cdot 3 ; \mathrm{MgSO}_{4}, 0 \cdot 1 ; \mathrm{CaCl}_{2}, 1 \cdot 1$. To each medium a solution of trace elements was added to give final concentrations $\left(\mu \mathrm{moll}^{-1}\right)$ of: $\mathrm{ZnSO}_{4}, 0.035 ;\left(\mathrm{NH}_{4}\right)_{6} \mathrm{Mo}_{7} \mathrm{O}_{24}$, 0.016; $\mathrm{CuSO}_{4}, 0.18$; and $\mathrm{FeSO}_{4}, 0.90$. Media were autoclaved at $115{ }^{\circ} \mathrm{C}$ for $20 \mathrm{~min}$ and then a solution of vitamins (sterilized by filtration) was aseptically added to give final concentrations $\left(\mu \mathrm{mol} \mathrm{l}^{-1}\right)$ of: mesoinositol, 110; pyridoxine hydrochloride, $2 \cdot 4$; calcium pantothenate, $4 \cdot 2$; nicotinic acid, 32 ; thiamin hydrochloride, $1 \cdot 2$; and biotin, 0.0041 .

Polyene antibiotics. Nystatin (potency 5614 i.u. $\mathrm{mg}^{-1}$, assumed to be $100 \%$ pure, mol. wt 927 ) and amphotericin B (potency $865 \mu \mathrm{g} \mathrm{ml}^{-1}$, mol. wt 959 ) were kindly donated by E. R. Squibb, Moreton, Merseyside. The activities quoted above were determined by the manufacturer's bioassay. Stock solutions of antibiotics $\left(32000 \mu \mathrm{g} \mathrm{ml}^{-1}\right)$ were prepared in dimethylformamide and stored at $-20^{\circ} \mathrm{C}$ in the dark.

Minimum inhibitory concentrations of both polyenes with respect to C. albicans 6406 were determined by the standard twofold dilution technique. From stock solutions appropriate dilutions were made in test tubes using CCM (all components in excess) to provide a series of concentrations ranging from 8 to 0.06 
$\mu \mathrm{g} \mathrm{ml}^{-1}$. Tubes were inoculated with $0.02 \mathrm{ml}$ of an $18 \mathrm{~h}$ culture which had been grown, with shaking, at $37^{\circ} \mathrm{C}$ in CCM. Tubes, including growth and sterility controls, were then incubated at $37^{\circ} \mathrm{C}$ for $18 \mathrm{~h}$, when growth was assessed. The minimum inhibitory concentration for nystatin was found to be $2 \mu \mathrm{g} \mathrm{ml}^{-1}(=2 \cdot 2$ $\mu \mathrm{M})$ and for amphotericin B, $0.25 \mu \mathrm{g} \mathrm{ml}^{-1}(=0.26 \mu \mathrm{M})$.

Preparation of standard cell suspensions. Batch cultures were harvested at appropriate times; continuous culture samples were taken directly from the vessel. Yeast concentration was determined by filtering $10 \mathrm{ml}$ samples through pre-weighed membrane filters (type GA3, pore size $1.2 \mu \mathrm{m}$; Gelman Hawksley, Lancing, Sussex), washing twice with distilled water and drying to constant weight in an oven at $90{ }^{\circ} \mathrm{C}$.

Cultures were centrifuged at $4000 \mathrm{~g}$ at $25^{\circ} \mathrm{C}$, washed twice in $0.05 \mathrm{M}$-Tris/ $\mathrm{HCl}$ buffer pH 7.5 and resuspended in this buffer to give a final concentration of approximately $1.0 \mathrm{mg} \mathrm{ml}^{-1}\left(0.21 A_{560} \approx 1.0 \mathrm{mg}\right.$ dry wt equivalent $\mathrm{ml}^{-1}$ ). Actual concentrations were then determined by membrane filtration as described above.

Measurement of potassium. In essence, the method of Gale (1974) was used. Potassium was estimated using a Philips $\mathrm{K}^{+}$specific electrode (model IS 560K, Pye Unicam) together with a Philips ground-glass double-junction reference electrode (model R44-2-SD/1, Pye Unicam). The membrane in the $\mathrm{K}^{+}$electrode (polyvinyl chloride impregnated with valinomycin in diphenyl ether) was changed every $10 \mathrm{~d}$. The reference electrode contained a bridge of $0 \cdot 1 \mathrm{M}-\mathrm{NaNO}_{3}$ which was frequently renewed. When not in use, both electrodes were stored in a solution of $0.1 \mathrm{M}-\mathrm{KCl} / 0.01 \mathrm{M}-\mathrm{NaCl}$ made up in $0.05 \mathrm{M}$-Tris/ $\mathrm{HCl}$ buffer $\mathrm{pH} 7.5$; before use both electrodes were well rinsed with buffer. The potential derived from the electrodes was measured with a Philips ion activity meter (model PW 9413, Pye Unicam) connected to a potentiometric recorder (Servoscribe model 543.20, Smiths Industries, Wembley, Middlesex). For $\mathrm{K}^{+}$determinations, electrodes were immersed in the sample, contained in a small beaker, which was stirred using a magnetic stirrer/flea and maintained at $25{ }^{\circ} \mathrm{C}$. Prior to any experimental assay, the system was calibrated using standard solutions of $\mathrm{KCl}$ in 0.05 M-Tris/HCl buffer pH 7.5.

Polyene-mediated $\mathrm{K}^{+}$release. Stock solutions of the antibiotics were diluted with $0.05 \mathrm{M}$-Tris/ $\mathrm{HCl}$ buffer pH 7.5 to give required concentrations. The steady-state $\mathrm{K}^{+}$level of washed standard suspensions was monitored for $5 \mathrm{~min}$; the appropriate amount of polyene in dimethylformamide/buffer was then added to give a final concentration of $8 \mu \mathrm{M}$ and the $\mathrm{K}^{+}$level was measured for a further $30 \mathrm{~min}$. The final concentration of dimethylformamide in these experiments was $0.66 \%(\mathrm{v} / \mathrm{v})$ which, when added alone to washed suspensions of $C$. albicans, showed no significant promotion of $\mathrm{K}^{+}$release.

Total free intracellular $\mathrm{K}^{+}$. Samples of washed, standardized suspensions were suspended in a boiling water bath for $15 \mathrm{~min}$, cooled to $25^{\circ} \mathrm{C}$ and the total $\mathrm{K}^{+}$released was measured as described above.

\section{RESULTS}

\section{Batch culture studies}

Cultures grown in Sabouraud medium and defined CCM (initial pH 5.0, incubated at $37^{\circ} \mathrm{C}$ ) were sampled after $6 \mathrm{~h}$ (early/mid-exponential phase) and $20 \mathrm{~h}$ (late-exponential/ early-stationary phase) and examined for their susceptibility to nystatin $(8 \mu \mathrm{M})$. On the basis of $\mathrm{K}^{+}$released per unit dry weight (Fig. $1 a$ ), young cultures grown in either medium were highly sensitive to nystatin as demonstrated by (i) the short lag before measurable $\mathrm{K}^{+}$ release occurred and (ii) the high maximum rate of release. As cultures aged, susceptibility was reduced.

Examination of the free intracellular $\mathrm{K}^{+}$levels (Table 1) revealed a difference between the cultures grown in the two media and harvested after the same length of incubation. The cultures grown in defined medium showed a higher $\mathbf{K}^{+}$content than those grown in Sabouraud medium. In both media, the cellular $\mathrm{K}^{+}$content decreased with the age of the culture. To take account of such different internal $\mathrm{K}^{+}$concentrations and to determine the influence of such differences upon the kinetics of nystatin-mediated $\mathbf{K}^{+}$release, the data presented in Fig. 1 $(a)$ and Table 1 were combined and replotted as the percentage of total free intracellular $\mathrm{K}^{+}$released against time. When presented in this manner (Fig. $1 b$ ), the patterns of $\mathrm{K}^{+}$release showed some significant changes as compared with Fig. 1(a). Although the lag times were unaltered, the other characteristics of the curves were changed. As a result of this finding, all subsequent $\mathrm{K}^{+}$release data were plotted on the basis of the percentage total free intracellular $\mathrm{K}^{+}$released. It remains clear from Fig. 1(b), however, that young cultures grown in either medium were almost equally susceptible to nystatin and that 
Table 1. Influence of culture age upon the total free $K^{+}$content of batch-grown cultures of C. albicans $\left(37^{\circ} \mathrm{C}\right.$; initial $\left.\mathrm{pH} 5 \cdot 0\right)$

$\begin{array}{lccc}\text { Medium } & \begin{array}{c}\text { Time of harvesting } \\ (\mathrm{h})\end{array} & \begin{array}{c}\text { Total free } \mathrm{K}^{+} \text {content }[\mathrm{nmol} \\ \left.(\mathrm{mg} \mathrm{dry} \mathrm{wt} \mathrm{equiv)})^{-1}\right]\end{array} & \begin{array}{c}\text { Intracellular } \mathrm{K}^{+} \\ \text {concn }(\mathrm{mM})^{*}\end{array} \\ \text { Sabouraud } & 6 & 410 \cdot 0 & 102 \cdot 5 \\ & 20 & 324 \cdot 0 & 81 \cdot 0 \\ \text { Defined } & 6 & 643 \cdot 0 & 160 \cdot 8 \\ & 20 & 521 \cdot 0 & 130 \cdot 2\end{array}$

* Assuming that (i) the cell water content is four times the dry mass and (ii) the density of cell water is $1 \cdot 0 \mathrm{~g} \mathrm{ml}^{-1}$.
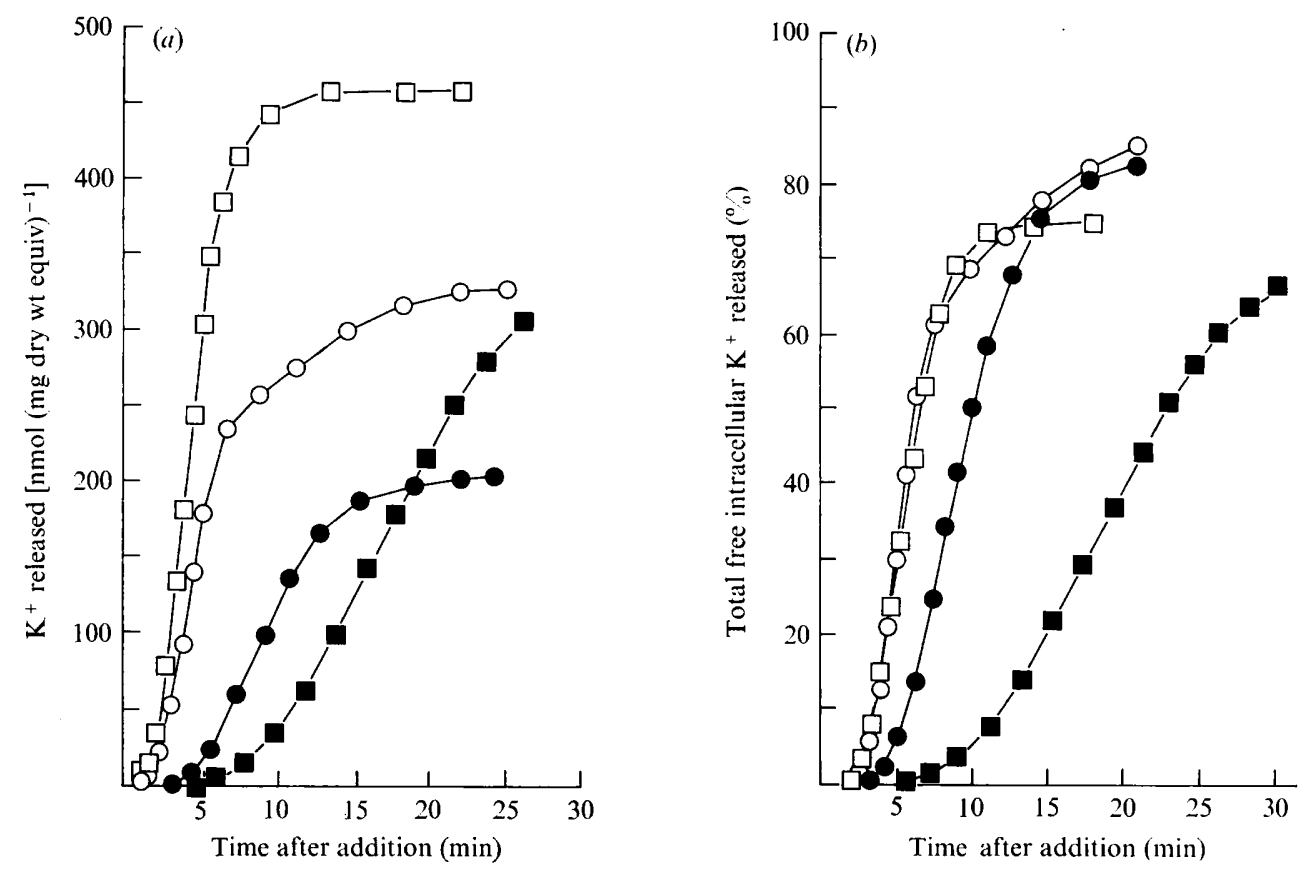

Fig. 1. Influence of culture age upon nystatin $(8 \mu \mathrm{M})$ mediated $\mathrm{K}^{+}$release from batch cultures of $C$. albicans $\left(37^{\circ} \mathrm{C}\right.$; initial pH 5.0) plotted as $(a) \mathrm{K}^{+}$released per unit dry weight and $(b)$ percentage of the total free intracellular $\mathrm{K}^{+}$released. Sabouraud medium, harvested after $6 \mathrm{~h}(\mathrm{O})$ and $20 \mathrm{~h}(\mathbf{0})$;

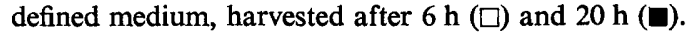

whilst ageing in either medium was associated with increased resistance to nystatin, this effect was much greater in cultures grown in defined medium than in those grown in the chemically more complex Sabouraud medium.

\section{Continuous culture studies}

Using chemostat cultures, the separate effects of (i) the nature of the growth-limiting substrate, (ii) growth rate, (iii) growth temperature and (iv) growth $\mathrm{pH}$ upon the sensitivity of $C$. albicans to nystatin and amphotericin B were determined. With the exception of substrate limitation experiments, nitrogen-limited cultures were used.

Substrate limitation. Cultures were established [growth rate $(\mu)=$ dilution rate $(D)=$ $0 \cdot 10 \mathrm{~h}^{-1}$; temperature $37^{\circ} \mathrm{C} ; \mathrm{pH} 5.0$ ] and the influence of substrate limitation with respect to carbon (C), nitrogen $(\mathrm{N})$, sulphur $(\mathrm{S})$, magnesium $(\mathrm{Mg})$ and phosphorus $(\mathrm{P})$ upon polyene-mediated $\mathrm{K}^{+}$release was examined. Variation of substrate limitation produced considerable changes in the free intracellular $\mathrm{K}^{+}$levels (Table 2), those of $\mathrm{C}$ - and $\mathrm{N}$-limited 

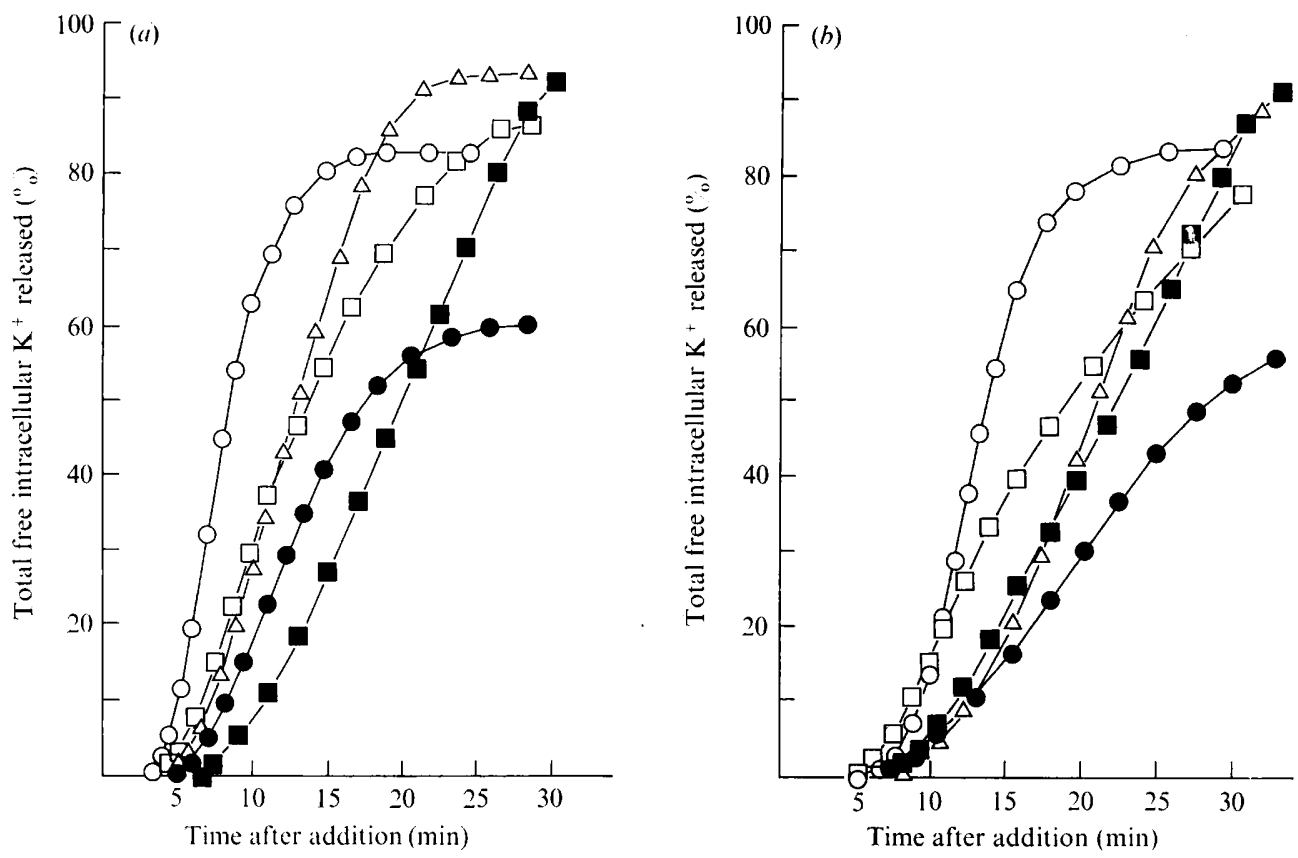

Fig. 2. Influence of substrate limitation upon $(a)$ nystatin $(8 \mu \mathrm{M})$ mediated and $(b)$ amphotericin B $(8 \mu \mathrm{M})$ mediated $\mathrm{K}^{+}$release from chemostat cultures of $C$. albicans $\left(D=0.10 \mathrm{~h}^{-1} ; 37^{\circ} \mathrm{C} ; \mathrm{pH} 5 \cdot 0\right)$ : $\bigcirc$, carbon limited; $\odot$, nitrogen limited; $\square$, sulphur limited; $\mathbf{1}$, magnesium limited; $\triangle$, phosphorus limited.

Table 2. Influence of substrate limitation, growth rate, growth temperature and growth $p H$ upon the total free $K^{+}$content of chemostat-grown cultures of $C$. albicans

\begin{tabular}{|c|c|c|c|c|c|}
\hline $\begin{array}{l}\text { Substrate } \\
\text { limitation }\end{array}$ & $\begin{array}{l}\text { Growth rate } \\
\quad\left(\mathrm{h}^{-1}\right)\end{array}$ & $\begin{array}{c}\text { Temperature } \\
\left({ }^{\circ} \mathrm{C}\right)\end{array}$ & $\mathrm{pH}$ & $\begin{array}{c}\text { Total free } \mathrm{K}^{+} \\
\text {content [nmol } \\
\left.\text { (mg dry wt equiv) }^{-1}\right]\end{array}$ & $\begin{array}{l}\text { Intracellular } \\
\mathrm{K}^{+} \text {concn* } \\
\quad(\mathrm{mM})\end{array}$ \\
\hline $\begin{array}{l}\text { Carbon } \\
\text { Nitrogen } \\
\text { Phosphorus } \\
\text { Magnesium } \\
\text { Sulphur }\end{array}$ & $0 \cdot 10$ & 37 & 5.0 & $\begin{array}{l}595 \cdot 7 \\
479 \cdot 4 \\
395 \cdot 0 \\
384 \cdot 9 \\
377 \cdot 9\end{array}$ & $\begin{array}{r}148 \cdot 9 \\
119 \cdot 9 \\
94 \cdot 8 \\
96 \cdot 2 \\
94.5\end{array}$ \\
\hline Nitrogen & $\begin{array}{l}0 \cdot 045 \\
0 \cdot 10 \\
0 \cdot 17\end{array}$ & 37 & $5 \cdot 0$ & $\begin{array}{l}640 \cdot 0 \\
479 \cdot 4 \\
533 \cdot 3\end{array}$ & $\begin{array}{l}160 \cdot 0 \\
119 \cdot 9 \\
133 \cdot 3\end{array}$ \\
\hline Nitrogen & $0 \cdot 10$ & $\begin{array}{l}22 \\
27 \\
32 \\
37 \\
42\end{array}$ & $5 \cdot 0$ & $\begin{array}{l}812 \cdot 0 \\
583 \cdot 3 \\
490 \cdot 5 \\
479 \cdot 4 \\
431 \cdot 2\end{array}$ & $\begin{array}{l}203 \cdot 0 \\
145 \cdot 8 \\
122 \cdot 4 \\
119 \cdot 9 \\
107 \cdot 8\end{array}$ \\
\hline Nitrogen & $0 \cdot 10$ & 37 & $\begin{array}{l}3 \cdot 0 \\
5 \cdot 0 \\
7 \cdot 0\end{array}$ & $\begin{array}{l}500 \cdot 0 \\
479 \cdot 4 \\
426 \cdot 0\end{array}$ & $\begin{array}{l}125 \cdot 0 \\
119 \cdot 9 \\
106 \cdot 5\end{array}$ \\
\hline
\end{tabular}

* Assuming that (i) the cell water content is four times the dry mass and (ii) the density of cell water is $1.0 \mathrm{~g} \mathrm{ml}^{-1}$.

cultures being higher than the others. The $\mathrm{K}^{+}$release plots obtained with nystatin (Fig. $2 a$ ) showed C-limited cultures to be most sensitive and $\mathrm{Mg}$-limited cultures least sensitive. With amphotericin B (Fig. 2b), C-limited cultures again showed the highest susceptibility but in this case N-limited cultures were least susceptible. Comparison of Figs. 2(a) and 


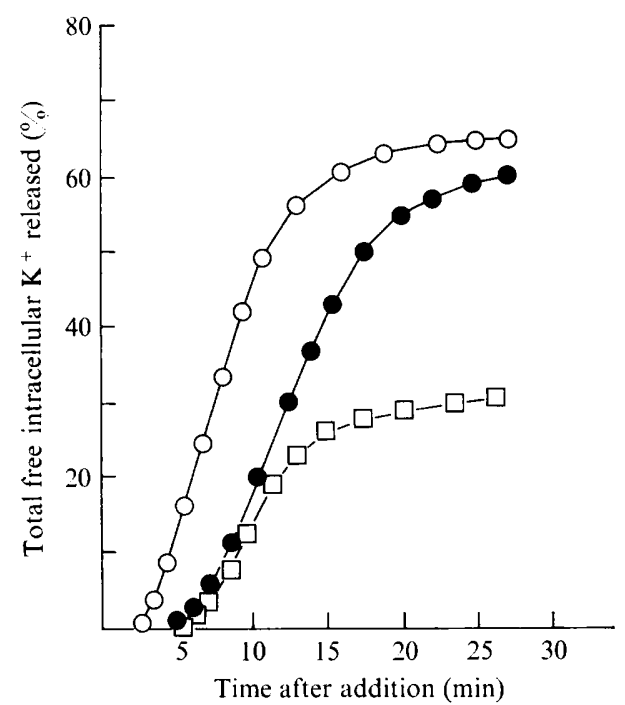

Fig. 3

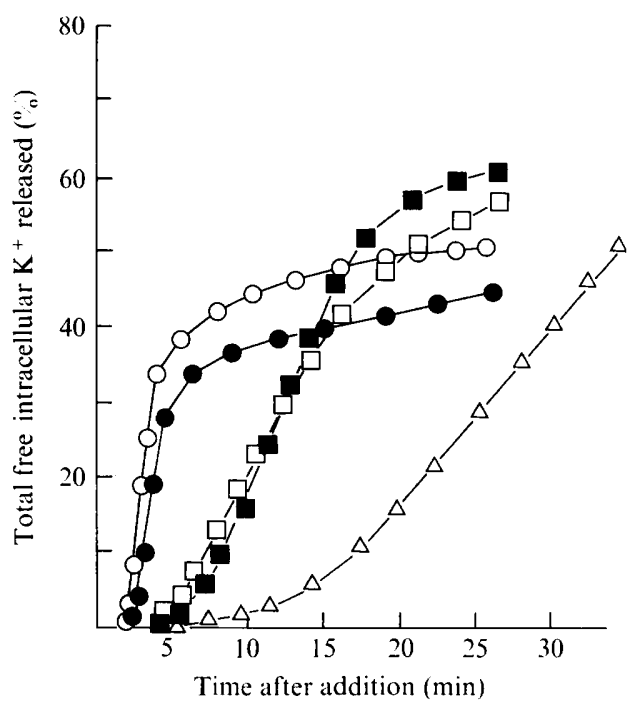

Fig. 4

Fig. 3. Influence of growth rate upon nystatin $(8 \mu \mathrm{M})$ mediated $\mathrm{K}^{+}$release from chemostat cultures of $C$. albicans (nitrogen limited; $37^{\circ} \mathrm{C}$; pH 5.0): $\bigcirc, D=0.17 \mathrm{~h}^{-1} ; 0, D=0.10 \mathrm{~h}^{-1} ; \square, D=0.045$ $\mathrm{h}^{-1}$.

Fig. 4. Influence of growth temperature upon nystatin $(8 \mu \mathrm{M})$ mediated $\mathrm{K}^{+}$release from chemostat cultures of $C$. albicans (nitrogen limited; $D=0 \cdot 10 \mathrm{~h}^{-1} ; \mathrm{pH} 5 \cdot 0$ ): $0,22^{\circ} \mathrm{C} ; 0,27^{\circ} \mathrm{C} ; \square, 32^{\circ} \mathrm{C}$; 匹, $37^{\circ} \mathrm{C} ; \triangle, 42^{\circ} \mathrm{C}$.

2(b) shows that (i) treatment of cultures with amphotericin B resulted in a much longer lag before measurable $\mathrm{K}^{+}$release occurred than with nystatin treatment, and (ii), whereas $\mathrm{C}$-, $\mathrm{S}-, \mathrm{Mg}$ - and P-limited cultures released a high proportion (about $90 \%$ ) of their free intracellular $\mathrm{K}^{+}$within 30 min after antibiotic treatment, $\mathrm{N}$-limited cultures showed a much lower percentage release (about 50 to $60 \%$ ). Both of these features were observed consistently throughout the present study.

Growth rate. Cultures were established [N-limited; temperature $37^{\circ} \mathrm{C} ; \mathrm{pH} \mathrm{5.0]}$ and the influence of growth rate upon polyene-mediated $\mathrm{K}^{+}$release was examined. Free intracellular $\mathrm{K}^{+}$levels showed little variation with growth rate (Table 2), although that resulting from growth at $\mu=0.045 \mathrm{~h}^{-1}$ was significantly higher than those observed at the faster growth rates. The $\mathrm{K}^{+}$release plot obtained with nystatin (Fig. 3) showed a relationship between polyene sensitivity and growth rate, cultures grown at $0.045 \mathrm{~h}^{-1}$ and $0 \cdot 10 \mathrm{~h}^{-1}$ showing essentially similar release patterns, whilst a higher growth rate $\left(0 \cdot 17 \mathrm{~h}^{-1}\right)$ resulted in an increased sensitivity to polyene. Similar results (data not shown) were obtained with amphotericin B.

Growth temperature. Cultures were established [N-limited; $\left.\mu=0 \cdot 10 \mathrm{~h}^{-1} ; \mathrm{pH} 5.0\right)$ and the influence of growth temperature upon polyene-mediated $\mathrm{K}^{+}$release was examined. There were considerable differences between the free intracellular $\mathrm{K}^{+}$levels of cultures grown at temperatures in the range 22 to $42^{\circ} \mathrm{C}$ (Table 2), those grown at lower temperatures showing higher concentrations. The $\mathrm{K}^{+}$release plot obtained with nystatin (Fig. 4) indicated an inverse relationship between growth temperature in the range 22 to $42{ }^{\circ} \mathrm{C}$ and polyene sensitivity - the lower the temperature, the higher the sensitivity. It was particularly noticeable that cultures grown at $42{ }^{\circ} \mathrm{C}$ showed a marked reduction in sensitivity compared with those grown at $37^{\circ} \mathrm{C}$. Essentially similar results (data not shown) were obtained with amphotericin B.

Growth $p H$. Cultures were established [N-limited; $\mu=0 \cdot 10 \mathrm{~h}^{-1}$; temperature $37^{\circ} \mathrm{C}$ ] and the influence of growth $\mathrm{pH}$ upon polyene-mediated $\mathrm{K}^{+}$release was examined. Once again, 


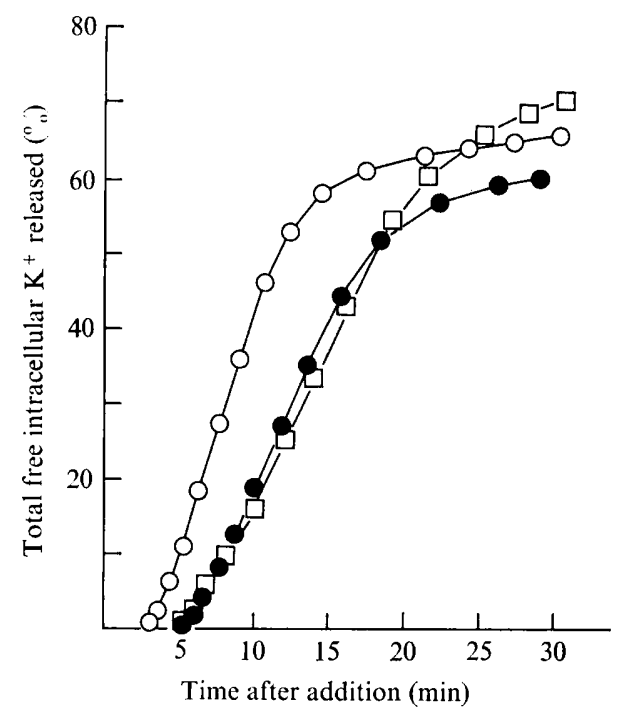

Fig. 5. Influence of growth $\mathrm{pH}$ on nystatin $(8 \mu \mathrm{M})$ mediated $\mathrm{K}^{+}$release from chemostat cultures of C. albicans (nitrogen limited; $D=0.10 \mathrm{~h}^{-1} ; 37^{\circ} \mathrm{C}$ ): $\bigcirc, \mathrm{pH} 3 \cdot 0 ; 0, \mathrm{pH} 5 \cdot 0 ; \square, \mathrm{pH} \mathrm{7.0.}$

the free intracellular $\mathrm{K}^{+}$concentration was a function of growth conditions (Table 2), the highest value being obtained at $\mathrm{pH} 3.0$ and the lowest at $\mathrm{pH} 7 \cdot 0$. The $\mathrm{K}^{+}$release plot obtained with nystatin (Fig. 5) showed that growth at low pH (3.0) resulted in a marked increase in polyene susceptibility compared with growth at $\mathrm{pH} 5.0$ and 7.0 which led to essentially similar sensitivities. The release plots obtained with amphotericin B (not shown) showed similar trends.

\section{DISCUSSION}

Whilst the use of $\mathrm{K}^{+}$-specific electrodes provides a convenient method for monitoring the interaction between polyenoic antibiotics and susceptible organisms, the present findings show that care is required in the assessment of the significance of results obtained by the use of such methods. In C. albicans 6406 , the intracellular levels of free $\mathrm{K}^{+}$in both batch and continuous cultures show relatively large fluctuations in response to growth conditions, as has also recently been reported in C. utilis (Aiking \& Tempest, 1976). Therefore, if the kinetics of $\mathrm{K}^{+}$efflux are to be used to monitor the yeast/polyene interaction, then it is important to take account of the internal free $\mathrm{K}^{+}$concentration of the cultures used. Such considerations have been largely ignored in studies of this type, although Hammond et al. (1974) quoted values for non-bound cellular $\mathrm{K}^{+}$in their investigation into the effects of nystatin, amphotericin B and candicidin upon batch-grown cultures of $C$. albicans NCTC 713. It is of interest that whilst these authors found the $\mathrm{K}^{+}$levels of such cultures to be comparable, in the present study we observed considerable variations in the $\mathrm{K}^{+}$content of similar cultures.

The present investigation has confirmed that the polyene sensitivity of batch-grown C. albicans is a function of culture age (Hammond et al., 1974; Gale, 1974), and has shown the nature of the growth medium to be important in this regard. However, the use of the chemostat has been necessary to show unequivocally that the physiological state of the organism is a critical factor in determining the rate and extent of the interaction with polyene. Several parameters of growth, often indistinguishable in batch culture, have been shown to influence the physiological state and, thus, the interaction with nystatin and amphotericin B. Growth rate, nature of the growth-limiting substrate, temperature and $\mathrm{pH}$ of growth have all been shown to influence sensitivity, as monitored by $\mathrm{K}^{+}$release. 
It has been suggested that observed variations in the polyene sensitivity of batch-grown C. albicans may have been due to differences in the structure and composition of the cell wall, thereby modulating access of the antibiotics to the plasma membrane (Gale, 1974; Hammond \& Kliger, 1974; Gale et al., 1975; Archer \& Gale, 1975; Kerridge, Koh \& Johnson, 1976; Gale, Johnson \& Kerridge, 1977). The variations in sensitivity described in the present paper can probably be ascribed to a multiplicity of changes, both qualitative and quantitative, at the cell surface either in the plasma membrane or the cell wall or both. In the absence of detailed chemical analysis of these structures isolated from cultures grown under defined conditions, it is possible only to speculate as to the possible identity of components which might be responsible for the observed changes in sensitivity. Clearly, analyses of carbohydrate, lipid and protein components are of paramount importance in this regard.

Two further points arising out of the present study are worthy of comment. First, although the minimum inhibitory concentration of amphotericin B is less than that of nystatin (by a factor of approximately 10), amphotericin B was consistently less efficient at promoting $\mathrm{K}^{+}$release than nystatin. The possible reasons for this are not clear. Second, relatively low polyene-mediated percentage $\mathrm{K}^{+}$release was consistently observed with $\mathrm{N}$-limited cultures. This implies that a proportion of the total cellular $\mathrm{K}^{+}$, released by boiling, may be bound during growth and thus not available for release upon treatment with polyenes. It would be of considerable interest to investigate further such reduced availability of $\mathrm{K}^{+}$ and why this should be a property of $\mathrm{N}$-limited cultures.

In conclusion, the present study has shown the importance of the physiological state of C. albicans in relation to the interaction with polyenoic antibiotics and has underlined the enormous potential of the chemostat in investigations of this kind. The undoubted importance of the physiological state of susceptible organisms in their interaction with antibiotics is only now being realized, and in vitro studies employing chemostat cultures should be of great value in the elucidation of the highly complex interactions which must occur in vivo.

Our thanks are due to Alan Bradley for his competent technical assistance with part of this work.

\section{REFERENCES}

Aiking, H. \& Tempest, D. W. (1976). Growth and physiology of Candida utilis N.C.Y.C. 321 in potassium limited chemostat culture. Archives of Microbiology 108, 117-124.

ArCheR, D. B. \& Gale, E. F. (1975). Antagonism by sterols of the action of amphotericin and filipin on the release of potassium ions from Candida albicans and Mycoplasma mycoides subsp. capri. Journal of General Microbiology 90, 187-190.

Borowski, E. \& Cybulska, B. (1967). Potassiumless death of Saccharomyces cerevisiae cells treated with $N$-succinyl perimycin and the reversal of fungicidal action of the antibiotic by potassium ions. Nature, London 213, 1034-1035.

Cartwright, R. Y. (1975). Antifungal drugs. Journal of Antimicrobial Chemotherapy 1, 141-162.

FINCH, J. E. \& Brown, M. R. W. (1975). The influence of nutrient limitation in a chemostat on the sensitivity of Pseudomonas aeruginosa to polymyxin and EDTA. Journal of Antimicrobial Chemotherapy 1, 379-386.

Gale, E. F. (1974). The release of potassium ions from Candida albicans in the presence of polyene antibiotics. Journal of General Microbiology 80, $451-465$.
Gale, E. F., Johnson, A. M., Kerridge, D. \& KoH, T. Y. (1975). Factors affecting the changes in amphotericin sensitivity of Candida albicans during growth. Journal of General Microbiology 87, 20-36.

Gale, E. F., Johnson, A. M. \& Kerridge, D. (1977). The effect of aeration and metabolic inhibitors on resistance to amphotericin in starved cultures of Candida albicans. Journal of General Microbiology 99, 77-84.

Hamilton-MilleR, J. W. T. (1973). Chemistry and biology of the polyene macrolide antibiotics. Bacteriological Reviews 37, 166-196.

Hammond, S. M. \& KLIGER, B. N. (1974). Studies on the role of the cell wall of Candida albicans in the mode of action of polyene antibiotics. Proceedings of the Society for General Microbiology 1, 45.

Hammond, S. M., Lambert, P. A. \& Kliger, B. N. (1974). The mode of action of polyene antibiotics; induced potassium leakage in Candida albicans. Journal of General Microbiology 81, 325-330.

Holz, R. W. (1974). The effects of the polyene antibiotics nystatin and amphotericin $\mathbf{B}$ on thin 
lipid membranes. Annals of the New York Academy of Sciences 235, 469-479.

Kerridge, D., KoH, T. Y. \& Johnson, A. M. (1976). The interaction of amphotericin B methyl ester with protoplasts of Candida albicans. Journal of General Microbiology 96, 117-123.

LAMPEN, J. O. (1966). Interference by polyene antifungal antibiotics (especially nystatin and filipin) with special membrane functions. Symposia of the Society for General Microbiology 16, 111-130.
McLaughlin, S. \& Eisenberg, M. (1975). Antibiotics and membrane biology. Annual Review of Biophysics and Bioengineering 4, 335-366.

Venables, P. \& Russell, A. D. (1975). Nystatin induced changes in Saccharomyces cerevisiae. Antimicrobial Agents and Chemotherapy 7, 121127.

ZYGMUNT, W. A. (1966). Intracellular loss of potassium in Candida albicans after exposure to polyene antifungal antibiotics. Applied Microbiology 14, 953-956. 